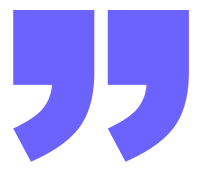

\title{
PIDGIN ENGLISH SPOKEN BY PAPUA NEW GUINEA PEOPLE IN YOUTUBE VIDEOS
}

\author{
Febrianus Wengkea1, I G. B. Wahyu Nugraha Putra², I Made Iwan \\ Indrawan Jendra ${ }^{3}$ \\ Mahasaraswati Denpasar University, Indonesia ${ }^{1,2,3}$ \\ febrianojansen768@gmail.com,wahyunugraha1980@yahoo.com, \\ iwanindrawan300573@gmail.com
}

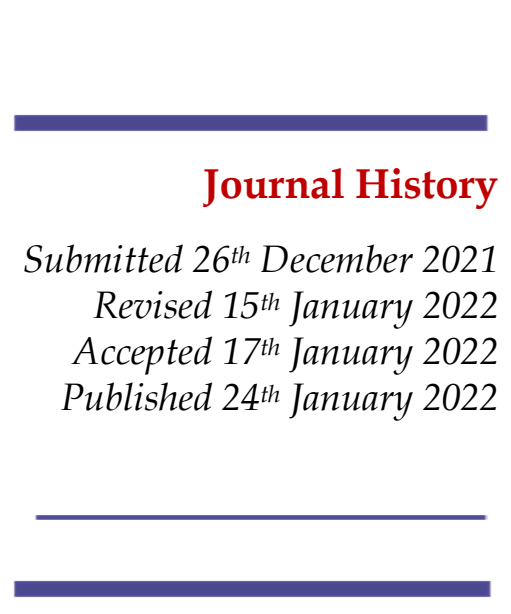

Keywords:

Pidgin English, Papua New Guinea, Standard English

\begin{abstract}
This research deals with Pidgin English spoken by Papua New Guineans found in YouTube videos. This study aims to identify the types of sentences in Pidgin English used by the people of Papua New Guinea and the differences between Pidgin English from Standard English. This study uses qualitative methods to carry out a clear and organized description of the problems identified. The data is taken from the narratives of Papua New Guineans found in YouTube videos. Applying Muhlhausler's (1978) theory to analyze the types of sentences used by Papua New Guineans found in YouTube videos and theory by Aitchison (1991) to distinguish between Pidgin English and Standard English. This study finds data based on the first study problem about sentence types such as the equative sentence mi citizen bilong la country 'We are the community on this country,' locative sentence yupela from East Sepik Province 'you are from East Sepik Province,' intransitive sentence mipela $i$ simenim $i$ go bek 'I am comment to return, and 'transitive sentence mi wokim ho na long em 'I am help them all.' The data contained in the second problem of research on differences in Pidgin English from Standard English such as the phonology em planti samting 'there are more,' the syntax so mi makim PNG 'so I marked PNG,' the dispela is lexicon of 'this is/is.'
\end{abstract}




\section{INTRODUCTION}

The need for language in society as a liaison between human interactions in social life, that's how it happens in language contact. It is the contact of two or three different languages because they are used by people who may not be native speakers of that language. It is a sociolinguistic situation in which two or more languages, different linguistic elements, or varieties in language, are used simultaneously or mixed with each other. One specific sociolinguistic condition of contact language is known as Pidgin. Pidgin speakers utilize unsatisfactory jargon and talk ungrammatically. Even though it's anything but a standard language, pidgin could be perceived by individuals who are regularly with regards to the collaboration. A large portion of pidgin dialects showed up in social orders who do exchanging. It is utilized between unfamiliar individuals to neighborhood individuals since it can fulfill each other connection while changing the data about selling and purchasing, as most of pidgin languages appeared in trading societies. According to Wardhaugh (in Jendra 2010; 148) "a Pidgin is the product of a multilingual situation where those wishing to communicate must invent or improvise simple code that allows them to do so. It is a reduce variety of a normal language with simplification of the grammar and vocabulary."

In the case of Pidgin language particularly on this study about Pidgin English from the basis of English which is mixed in use, simplification, and even changes in structure by the people of Papua New Guinea. That was happen since the colonization and trade in the century, England with their British English had influenced the community in Papua New Guinea. Pidgin English was used as the business language for group controls, the goods, and human labor being traded. The lexicon of the language was used to name both the goods and the laborers being sold or indentured. The Pidgin language has influenced Papua New Guinea since the 17th century. The Pidgin language spoken in Papua New Guinea is called Tok Pisin or Pidgin Melanesian. Tok Pisin as English pronunciation: /tok pisin/, in Tok Pisin: / tok pi'sin/), is often referred to by English speakers as "New Guinea Pidgin" or simply "Pidgin." The Tok Pisin writing system uses the Latin script or the Tok Pisin alphabet. The name "Tok" comes from the English "talk", but can also mean "word", "speech", or "language" and Pisin comes from the English word pidgin; the latter, in turn, may derive from the word "business" as the language of interethnic commerce. Higher linguistic diversity and deliberately cultivated as a situation where pidgin is considered by the social, Cameroon and Papua New Guinea still obtain this kind of situation.

The phenomenon of the pidgin language, especially the English pidgin language, is very interesting to be studied more deeply as in this 
study, it is based on reviewing previous research. Here the author found one of previous research taken from international journal. A previous study focused on "An Analysis the Use of Pidgin in Achebe's Man of the People" written by Jane and Chiagozie (Volume 21, Issue 1, Ver. IV (Jan. 2016) PP 01-05). The data sources of this study take from A Man of the People Novel. On their study to analyze the problem of language expression when pidgin came into use, English had acquired some local coloring that made African literature unique. The processing to accommodate the date, they taken convergence and divergence, that the theory of Giles and Coupland (1997). After that the data analyze using the textual analysis method. The author shows the extent as the analysis used of pidgin to add aesthetic value to his literary work. Therefore, this research intends to "Analyze Sentences In Pidgin English Spoken By Papua New Guinea People In YouTube Videos." The objectives of this research are identifying the types of sentences in Pidgin English used by the Papua New Guinea people found in YouTube videos. And identify the differences between Pidgin English sentences used by the Papua New Guinea people found in YouTube videos from sentences in Standard English.

\section{METHODS}

In this study, the source of the data was taken from the communication of the people of Papua New Guinea contained in the YouTube video. Taken from the YouTube video channel EMTV Online, most of the news content takes place in PNG, some Papua New Guineans use English as a pidgin language. Because at first English was not their language of contact, so their English was influenced by British colonialism. They pidginize English with affection of their mother tongue. The data in this study were collected related to vocabulary and sentences through searching YouTube videos uploaded by Papua New Guineans. The appreciation is to watch and listen to the video over and over, after that pay attention to the part of the video where Papua New Guineans speak Pidgin English to get the data and taking notes the data related to analysis. What's more is using the English to Pidgin dictionary to clearly define the data. The data were analyzed based on Muhlhausler (1978), his theory to find out the types of sentences in Pidgin English used by the people of Papua New Guinea. Likewise, the theory of Aitchison (1991) clarifies the difference between Pidgin English and Standard English. Using these two theories to answer and describe the data based on the research problem, Pidgin English data were selected from vocabulary and sentences. There are two methods to find presentations such as formal and informal methods. Formal methods of data can be presented in the form of tables, charts, and graphs. Meanwhile, informal data can be presented descriptively. Similarly, the findings of this study are presented through informal methods. To answer and describe the data based on this research 
problem, Pidgin English data were selected from vocabulary and sentences.

\section{RESULTS}

\section{RESULT AND DISCUSSION}

In this study it was found that 51 data were obtained during the study from two videos of the YouTube channel EMTV News Online whose videos have Pidgin English spoken by Papua New Guineans. In this type of sentence, 32 data were found, which contained 8 equative data, 6 locative data, 7 intransitive data, and 11 transitive data. Likewise, the data contained in Pidgin English is different from Standard English, totaling 19 data based on 7 phonological data, 7 syntactic data, and 5 lexicon data.

\section{DISCUSSION}

This section allows you to offer your interpretation and explain the meaning of your results. Emphasize any theoretical or practical consequences of the results.

The Discussion section should be a reasoned and justifiable commentary on the importance of your findings. This section states why the problem is important; what larger issues and what propositions are confirmed or disconfirmed by the extrapolation of these findings to such overarching issues.

This section of research is a discussion to describe the data found during the research in YouTube videos. Regarding the problem of this research has been identified, which results from the discussion of this section to answer the problem of using Muhlhausler's (1978) theory to describe the data based on the type of sentence. Also use Aitchison's (1991) theory of the difference between Pidgin English and Standard English. To clarify the data, as previously mentioned, several dictionaries from Pidgin English to Standard English were used. The dictionaries used in this study include Glosbe Dictionary, Tok Pisin English Dictionary, Merriam Webster Dictionary, Oxford English Dictionary, and Cambridge Dictionary. Based on the data that has been found during the research, the discussion is below.

\section{Types of Sentence in Pidgin English use by Papua New Guinea People}

Based on the theory put forward by Muhlhausler (1978), the types of sentences can be divided into four types, including the equative sentence, which is the type of sentence used in linguistics which refers to the construction between two statements that are equated with each other such as to describe someone who states a sentence, locative sentence is a type of sentence. which usually has a locative adverb that is used to describe the location of someone or something, an intransitive sentence is 
a type of sentence that usually has an intransitive verb to describe someone or something that is not an activity that does not have a direct object, a transitive sentence is a type of sentence that usually has a verb transitive to describe someone or something that does an activity with a direct object.

Pidgin English data by type of sentence was collected from speeches by the people of Papua New Guinea in the YouTube video EMTV Online News with the video title "Sepik Chiefs Disappointed with Grand Chief Sir Michael Somares Farewell." Even the translator dictionary use to clarify data such as Glosbe Dictionary, Tok Pisin English Dictionary, Merriam Webster Dictionary, Oxford English Dictionary, and Cambridge Dictionary. The types of sentences in Pidgin English are discussed below.

\section{Equative Sentence \\ Data 1}

Mi la long olsem long kam up sensitive.

Should be,

'I am also come up very sensitive.'

(Source; EMTV Online News YouTube Channel in "Sepik Chiefs Disappointed with Cancellation of Grand Chief Sir Michael Somares Farewell.", 01; 05)

The sentence above is classified as an equivalent sentence with the placement of the long olsem 'also' to equate a sentence that becomes two statements in the same sentence. Even the speaker describes himself as a sensitive person.

\section{Locative Sentence \\ Data 2}

Mipela long Sepik.

Should be,

'We are from Sepik.'

(Source; EMTV Online News YouTube Channel in "Sepik Chiefs Disappointed with Cancellation of Grand Chief Sir Michael Somares Farewell." , 00; 19)

Based on the data above, it is identified as a type of locative sentence, in which it is noted that the speaker who states long Sepik 'from Sepik' as the object or location of the speaker states if he comes from Sepik. Likewise with Sepik which is one of the provinces in Papua New Guinea. 


\section{Intransitive Sentence}

\section{Data 3}

Mipela $i$ go rises long la said la week.

Should be,

'We research for talking last week.'

(Source; EMTV Online News YouTube Channel in "Sepik Chiefs Disappointed with Cancellation of Grand Chief Sir Michael Somares Farewell." , 01; 24)

The data above is found as an intransitive sentence because the sentence is identified as not containing a direct object. But the sentence describes someone who does an activity as in the statement $\mathrm{i}$ go rise 'research.'

\section{Transitive Sentence \\ Data 4}

Olsem na tokim long em.

Should be,

'Also tells to them.'

(Source; EMTV Online News YouTube Channel in "Sepik Chiefs Disappointed with Cancellation of Grand Chief Sir Michael Somares Farewell." , 01; 54)

The data above is identified as a transitive sentence where the sentence is identified as containing a direct object as in the state long em 'them/to them.' Even this sentence is spoken to indicate the person receiving the action verb as in tokim long em 'tell them.'

\section{Pidgin English Different from Standard English}

As Aitchison (1991) states, a pidgin is a finite language system that emerged to fulfill an essential communication need between people who do not share a common language and is usually based on one language, although it soon acquired a mix of other languages, as well as independent language constructs. Incorporating his theory in this research is used to discuss Pidgin English spoken by Papua New Guineans found on YouTube videos that are different from Standard English.

When collecting data on the use of Pidgin English in Papua New Guinea found on YouTube videos and comparing it to Standard English, the most obvious case is ignorance of grammar rules. Grammar as a system that makes language work plays an important role in a language, because it shows whether the language is considered grammatical or not. According to Aithchison (1991) Pidgin English is simpler than ordinary languages, especially Standard English based on Phonology, Syntax, and Lexicon. Including translator dictionaries used to clarify data such as 
Glosbe Dictionary, Tok Pisin English Dictionary, Merriam Webster Dictionary, Oxford English Dictionary, and Cambridge Dictionary. The differences between Papua New Guinean Pidgin English and Standard English can be discussed below.

\section{Phonology \\ Data 5}

Kontena lo we bek na go la Maprik small taun bilong mi.

Should be,

'We lock the container to go back to my village in Maprik.'

(Source: EMTV Online News Channel in "A Women Group is Against Nationwide Haus Krai" 00; 39)

The data above is found to be a form of phonological simplification, where some words in Pidgin English are different from standard English, such as lok 'lock,' bek 'back,' taun 'town.' However, the sound of these words is similar.

\section{Syntax}

Data 6

Em ol tu putim oda tu.

Should be,

'Two of them put on order two.'

(Source: EMTV Online News Channel in "A Women Group is Against Nationwide Haus Krai" 01; 13)

Based on the data, it has been identified as a syntax simplification due to the construction of sentences using different verbs such as transitive and intransitive verbs. Based on the two types of verbs related to the data above, such as putim construct of put $+\mathrm{im}$ as a typical transitive verb to add the suffix im. However, basically an intransitive verb whose construction does not add im, but instead contains an i particle in front of a verb such as i put. Even the sentences based on the data above turn into intransitive verbs such as em al oda tu i put 'two orders of them put two.'

\section{Lexicon}

\section{Data 7}

Naripela samting.

Should be,

'Something another.' 
(Source: EMTV Online News Channel in "A Women Group is Against Nationwide Haus Krai" 01; 28)

The above data is identified as a lexicon simplification because some Pidgin English words are different from Standard English. Based on the data above as in Pidgin English samting is different from Standard English 'something.' Which is where the standard English 'something' phoneme [a] shifts, [e] and [th] merge into Pidgin English samting.

\section{CONCLUSION}

After completing the findings and discussion here the researcher concludes the study of Pidgin English spoken by Papua New Guineans in YouTube videos. This study has identified four types of Pidgin English sentences according to the theory proposed by Mulhausler, namely equative is a sentence to describe someone or something, locative is a sentence to express an adverb of someone or something, intransitive is a sentence to describe someone who does an action without an direct object, and transitive is sentence to describe someone who does an activity to another person or something that receives the action of the verb in the sentence. The differences between Pidgin English and Standard English have also been discussed using the theory proposed by Aitchison's theory. Based on this research, it was found that the simplification of sounds from the phonological aspect in Pidgin English is different from Standard English. There are two syntaxes in pidgin English that differ from Standard English such as transitive whose verbs have a suffix or ending im and intransitive whose in the front of verbs have a standing particle $i$, and there is not even a specific structure to describe tenses. Similarly, aspects of the lexicon are simplified in Pidgin English by combining and shifting some word units or phonemes from Standard English. Pidgin English or Tok Pisin as a language rose from contact language to communication by Papua New Guinean people calling English versus Papua New Guinea's native language to Pidgin or Tok Pisin.

\section{REFERENCES}

Aitchison, Jean. 1991. Teach Yourself Linguistics-4th ed. British Library Cataloguing in Publication Data.

Bajao and Thomas 1991. Tok Pisin Grammar Workbook for English Speakers, A Practical Approach to Learning the Sentence Structure of Melanesian Pidgin (or Tok Pisin). Papua New Guinea: Peace Corps Institution.

..."East \& Southeast Asia: Papua New Guinea". CIA The World Fact book. Access on April, 01th 2021. 
https://www.cia.gov/the-world-factbook/countries/papua-new-guinea/ ...Glosbe Dictionary. Tok Pisin to English.

Jane and Chiagozie. 2016. An Analysis of The Use of Pidgin in Achebe's A Man of The People. IOSR Journal of Humanities and Social Science (IOSR-JHSS), V 21, Issue 1, Ver, IV (Jan. 2016) PP01-05, access on September 25th $2020 \quad$ www.iosjournals.org

Jendra M.I.I. 2010. Sociolinguistics, Study of Societies' Languages. Yogyakarta: Graha Ilmu.

Muhlhausler. P, 1978. Papers in Pidgin and Creole Linguistics No. 1. Australia: Department of Linguistics, Australian National University.

... Oxford Dictionary 2003. Oxford Learner Dictionary. Oxford, Oxford University Press.

...Papua New Guinea, Ethnologue. Access on April, 01th 2021.

http:/ / www.ethnologue.com/country/PG

Swadling, Pamela, 1996. Plumes from Paradise. Papua New Guinea National Museum.

... Tok Pisin Dictionary. Tok Pisin to English.

Trudgill. P, 2000. Sociolinguistics: An Introduction to Language and Society (4th edition). London: Pinguin Books.

Wardhaugh and Fuller, 2015. An Introduction to Sociolinguistics (7th edition). New Jersey: Blackwell Publishing.

Webster, Merriam Dictionary 1828. Language Detection to English. America. 